Meta

Journal des traducteurs

Translators' Journal

\title{
A Survey Among Audiences of Subtitled Films in Viennese Cinemas
}

\section{Brigitte Widler}

Volume 49, numéro 1, avril 2004

Traduction audiovisuelle

Audiovisual Translation

URI : https://id.erudit.org/iderudit/009025ar

DOI : https://doi.org/10.7202/009025ar

Aller au sommaire du numéro

Éditeur(s)

Les Presses de l'Université de Montréal

ISSN

0026-0452 (imprimé)

1492-1421 (numérique)

Découvrir la revue

Citer cet article

Widler, B. (2004). A Survey Among Audiences of Subtitled Films in Viennese Cinemas. Meta, 49(1), 98-101. https://doi.org/10.7202/009025ar
Résumé de l'article

À partir d'une enquête menée par interviews à Vienne (2002), on tente

d'apporter des réponses à des questions touchant le public des films sous-titrés. 


\title{
A Survey Among Audiences of Subtitled Films in Viennese Cinemas
}

\author{
BRIGITTE WIDLER \\ Professional Translator, Vienna, Austria \\ brigitte.widler@vienna.at
}

\section{RÉSUMÉ}

À partir d'une enquête menée par interviews à Vienne (2002), on tente d'apporter des réponses à des questions touchant le public des films sous-titrés.

\section{ABSTRACT}

A survey was conducted in Vienna in 2002 to get answers to questions concerning the target audience for subtitled films.

\section{MOTS-CLÉS/KEYWORDS}

audience, cinema-goers, interview, subtitles

\section{Background of the study}

This paper is based on a study carried out within a large-scale research project on "Literary translation as multimedial communication," organized by the Chair of Translation Studies at the University of Vienna and funded by the Austrian Science Foundation (FWF).

In the course of my research into subtitling activities in Austria it soon became clear that not a lot is known about the target audience of subtitled films. Who are those people who go and watch a subtitled film in a cinema? How often do they go to the cinema? Why do they choose a subtitled rather than a dubbed version? What are their experiences with subtitles in general and how satisfied are they with their quality? Where do they see the positive and/or negative aspects of subtitling? What are their educational and professional backgrounds? And how important are foreign languages in their professional lives?

To find answers to all these questions, a questionnaire (see annex) was set up in consultation with my colleague Anneliese Spitaler (who was also responsible for the final evaluation of the completed questionnaires in SPSS). The survey was conducted in Viennese cinemas on a total of 10 days between mid-August and mid-September 2002. Of the approximately 30 cinemas open for business over that period, seven regularly showed subtitled films. In addition, a number of summer film festivals screened subtitled films at irregular intervals. Details regarding cinemas, films and screening times were taken from Der Standard (an Austrian daily newspaper) and from Falter (a weekly city guide to Vienna). The interviews were conducted with 100 viewers of 19 different films in 9 different original-language versions ${ }^{1}$, all of them subtitled into German, in all seven aforementioned cinemas ${ }^{2}$ and at two film festival venues $^{3}$. Screening times ranged from mid-afternoon to late at night. Before the interviewers started to ask potential interviewees for their cooperation, permission to 
do so was obtained from cinema staff. Customers were approached immediately after they had bought their tickets. The interviewers first introduced themselves and gave some background information on the survey. The response was generally very positive and sometimes people appeared to be glad to be given the chance to voice their opinions, to talk about their experiences and to be taken seriously as customers. The questions were asked strictly in the order they appeared on the questionnaire, and answers were noted by the interviewers rather than letting people fill in the answers themselves. This guaranteed that all returned questionnaires were complete and that entries were clear and legible.

An average interview lasted between 5 and 10 minutes. As cinema-goers do not usually come to the cinema a long time in advance, sometimes only two or three people could be interviewed before the film started. This made progress very slow and on two days the assistance of colleagues was enlisted which speeded up the whole process considerably.

\section{Hypotheses and main results}

At the outset of the survey six hypotheses had been defined and these were either verified or shown to be false by the questionnaire results.

Hypothesis 1: The majority of the interviewees are from 31-50 years old. Only $48 \%$ of the interviewees fell into that age group. Hypothesis 1 is false.

Hypothesis 2: The majority of the interviewed viewers of subtitled cinema films hold a university degree.

$51 \%$ of the interviewees stated that they had graduated from a university. Hypothesis 2 is verified.

Hypothesis 3: The majority of the interviewed viewers of subtitled cinema films go to the cinema regularly (i.e. at least several times a month). (see question no. 1 of the questionnaire)

$6 \%$ of the interviewees go to the cinema several times per week, $16 \%$ once a week and $43 \%$ several times a month. A total of $65 \%$ go to the cinema at least several times a month. Hypothesis 3 is verified.

Hypothesis 4: Subtitles in the cinema do not play an important role in learning a foreign language (less than 10\%).

The evaluation of the answers to question no. 5 of the questionnaire showed that $57 \%$ of those interviewed stated that watching a subtitled film in the cinema helps them learn a language or improve their knowledge of a language. 16\% declared this their main reason for watching a subtitled film in the cinema. Hypothesis 4 was false.

Hypothesis 5: The majority of the interviewed viewers of subtitled cinema films were happy with the quality of the subtitles (grades 1 and 2). (see question no. 9 of the questionnaire)

$1 \%$ of the interviewees awarded grade 1 and $50 \%$ awarded grade 2 , bringing the total to $51 \%$. Hypothesis 5 was verified. 
Hypothesis 6: The majority of the interviewed viewers of subtitled cinema films would like more subtitled films to be shown in the cinema.

$61 \%$ of the interviewees stated that there are not enough subtitled films shown in the cinemas. Hypothesis 6 was verified.

Four of the six hypotheses were verified by the survey, two hypotheses were shown to be false. The response from both the cinema staff and the interview partners was very encouraging. There is definitely demand for more subtitling in Vienna's cinemas and even though there is always room for improvement audiences are generally content with the quality of the subtitles. It is now up to the film distribution companies to respond to their customers.

\section{NOTES}

1. Amores Perros (Spanish), Ayurveda (various Indian languages, English), La Comunidad (Spanish), La double vie de Veronique (French), Elsewhere (various languages), Le fate ignoranti (Italian), Gosford Park (English), Hable con ella (Spanish), I earini syntaxis ton agrofylakon (Greek), Jalla! Jalla! (Swedish), Jeder ist ein Star (Dutch), Land and Freedom (English), Mademoiselle (French), La messa è finita (Italian), My Own Private Idaho (English), Nobody's Business (English), Ratcatcher (English), Le roi danse (French), The Royal Tenenbaums (English).

2. Votivkino, Filmcasino, Schottentor, Admiral, Schikaneder, Stadtkino, Filmhaus

3. Augarten, Arena

\section{ANNEX}

\section{Questionnaire}

1. How often on average do you go to the cinema?

- several times per week

- once a week

- several times per month

- once a month

- several times per year

- less often

2. How often do you watch subtitled films?

- always

- often

- rarely

3. Why do you watch subtitled films? (open question)

4. Which language version do you prefer in the cinema?

- original version

- dubbed version

5. I will now list a number of reasons why somebody might watch a subtitled film. Which of these apply to you?

- because most of the films I am interested in are not available dubbed

- to learn / improve my knowledge of the language

- because dubbing makes a film less authentic

- because the original voices are important in a film

- other reasons:

6. Which of these is your main reason?

7. Are there enough subtitled films shown in the cinemas?

- yes, enough

- no, there should be more 
8. If you think of subtitles in general, where, apart from the cinema, have you come across them?

- television $\rightarrow>$ which channel

- video / DVD

- internet

- other:

9. How would you rate the quality of subtitles in general? $(1=$ very good, $5=$ very poor $)$ :

9 a. If grades 1 or 2 : what do you like about them?

9 b. If grades 3,4 or 5 : what do you not like about them?

10. Sex

- female

- male

11. Age

$$
\begin{aligned}
& \text { - under } 20 \\
& \text { - } 21 \text { to } 30 \\
& \text { - } 31 \text { to } 40 \\
& \text { - } 41 \text { to } 50 \\
& \text { - } 51 \text { to } 60 \\
& \text { - over } 60
\end{aligned}
$$

12. What is your highest completed level of education?

- Hauptschule (compulsory schooling until the age of 15)

- Lehre / berufsbildende Schule (apprenticeship / lower vocational school)

- AHS/BHS (A-levels)

- Hochschule / Universität / Fachhochschule (university degree)

13. What is your profession? What do you do for a living?

14. Do you need foreign languages in your job?

- yes, often

- yes, sometimes

- no, never

15. Your mother tongue
- German
- English
- French
- Italian
- Other:

16. Of which other languages do you have at least a basic knowledge?
- German
- English
- French
- Italian
- Other: 